\begin{tabular}{|c|c|}
\hline Title & Clinical significance of minimal residual disease in adult acute lymphoblastic leukemia \\
\hline Author(s) & $\begin{array}{l}\text { Kikuchi, Misato; T anaka, Junji; Kondo, T akeshi; Hashino, Satoshi; Kasai, Masaharu; Kurosawa, Mitsutoshi; I wasaki, } \\
\text { Hiroshi; Morioka, Masanobu; Kawamura, T sugumichi; Masauzi, Nobuo; Fukuhara, T akashi; Kakinoki, Y asutaka; } \\
\text { Kobay ashi, Hajime; Noto, Satoshi; A saka, Masahiro; Imamura, Masahiro }\end{array}$ \\
\hline Citation & $\begin{array}{l}\text { International Journal of Hematology, 92(3), 481-489 } \\
\text { https://doi.org/10.1007/s12185-010-0670-1 }\end{array}$ \\
\hline Issue Date & $2010-10$ \\
\hline Doc URL & http:/hdl.handle.net/2115/44159 \\
\hline Rights & The final publication is available at www.springerlink.com \\
\hline Type & article (author version) \\
\hline File Information & IJH92-3_481-489.pdf \\
\hline
\end{tabular}

Instructions for use 


\title{
Clinical significance of minimal residual disease in adult acute lymphoblastic leukemia
}

\begin{abstract}
Misato Kikuchi ${ }^{1)}$, Junji Tanaka ${ }^{1), ~ *, ~ T a k e s h i ~ K o n d o ~}{ }^{2)}$, Satoshi Hashino ${ }^{2)}$, Masaharu Kasai ${ }^{3)}$, Mitsutoshi Kurosawa ${ }^{4)}$, Hiroshi Iwasaki ${ }^{5)}$, Masanobu Morioka ${ }^{6}$, Tsugumichi Kawamura ${ }^{7)}$, Nobuo Masauzi ${ }^{8)}$, Takashi Fukuhara ${ }^{9)}$, Yasutaka Kakinoki ${ }^{10)}$, Hajime Kobayashi ${ }^{11)}$, Satoshi Noto ${ }^{12)}$, Masahiro Asaka ${ }^{2)}$, and Masahiro Imamura ${ }^{1)}$
\end{abstract}

${ }^{1)}$ Department of Hematology and Oncology, ${ }^{2)}$ Third Department of Internal Medicine, Hokkaido University Graduate School of Medicine.

${ }^{3)}$ Department of Hematology, Sapporo Hokuyu Hospital.

${ }^{4)}$ Department of Hematology, National Hospital Organization, Hokkaido Cancer Center.

${ }^{5)}$ Second Department of Internal Medicine, Sapporo Kosei Hospital.

${ }^{6)}$ Department of Internal Medicine, Aiiku Hospital.

${ }^{7)}$ Department of Internal Medicine, Hakodate Central Hospital.

${ }^{8)}$ Department of Hematology, Hakodate City Hospital.

${ }^{9)}$ Department of Internal Medicine, Asahikawa City Hospital.

${ }^{10)}$ Department of Internal Medicine, Asahikawa Kosei Hospital.

${ }^{11)}$ Fourth Department of Internal Medicine, Obihiro Kosei Hospital.

${ }^{12)}$ Department of Internal Medicine, Kushiro Rosai Hospital. 
* Corresponding author. Junji Tanaka, Department of Hematology and Oncology, Hokkaido University Graduate School of Medicine, N15, W7, Kita-ku, Sapporo, Hokkaido, 060-8648, Japan. Phone: +81 11 706 7214; Fax: +81 117067823.

E-mail address: jutanaka@med.hokudai.ac.jp (J. Tanaka) 


\begin{abstract}
Monitoring minimal residual disease (MRD) in patients with acute lymphoblastic leukemia (ALL) is a useful way for assessing treatment response and relapse.
\end{abstract}

We studied the value of MRD and showed a correlation with relapse for 34 adult patients with ALL. MRD was evaluated by real-time quantitative polymerase chain reaction (RQ-PCR) with probes derived from fusion chimeric genes (BCR/ABL) $(n=12)$ or PCR-based detection of clonal immunoglobulin and T-cell receptor gene rearrangements $(n=16)$, or both $(n=6)$. We analyzed 27 of the 34 patients who could be examined for MRD on day 100 after induction therapy. The overall survival (OS) rate $(45.0 \%)$ and relapse-free survival (RFS) rate $(40.0 \%)$ at 2 years in CR patients with MRD level $\geq 10^{-3}(n=12)$ were significantly lower than those in CR patients with MRD level $<10^{-3}(\mathrm{n}=15)(\mathrm{OS}$ rate: $79.0 \%$, RFS rate: $79.4 \%)$ (log-rank test, $P=0.017$ and 0.0007). We also applied multicolor flow cytometry for comparison with MRD results analyzed by PCR methods. The comparison of results obtained in 27 follow-up samples showed consistency in 17 samples $(63.0 \%)(P=0.057)$. MRD analysis on day 100 is important for treatment decision in adult ALL.

Key words: MRD; adult ALL; allogeneic transplantation; polymerase chain reaction; flow cytometry 


\section{Introduction}

The prognosis of adult patients with acute lymphoblastic leukemia (ALL) is dismal.

Although most adult patients with ALL enter complete remission (CR), only $30 \%$ to

$40 \%$ of patients survive 5 or more years (1). The major cause of treatment failure is

relapse, affecting approximately half of the patients who have achieved CR (2). Survival

depends on risk factors such as age, white blood cell (WBC) count, time to CR, disease

immunophenotype, cytogenetics, and molecular abnormalities (1), and several studies

have shown that detection of minimal residual disease (MRD) in childhood and adult

ALL is an independent risk parameter of high clinical relevance (3). Early indicators of

disease outcome would be particularly useful for the design of new treatments.

The rationale of MRD analysis is to improve estimation of treatment response, to

provide independent prognostic information, and to optimize therapeutic strategies.

Established methods for detecting MRD are polymerase chain reaction (PCR)

amplification of antigen receptor genes and of fusion transcripts and flow cytometric

detection of ectopic or aberrant immunophenotypes (4).

Flow cytometric detection of MRD is based on the identification of immunophenotypic

combinations expressed on leukemic cells but not on normal hematopoietic cells (4).

Abnormal antigen expression or leukemia-specific gene rearrangements or fusion 
transcripts are suitable for MRD detection; however, they cannot be identified in all

patients. Therefore, the complementary use of both methods might allow monitoring of virtually all patients for MRD.

We previously reported that molecular MRD status by PCR amplification of antigen receptor genes is a strong predictor of outcome in adult ALL (5). In this study, we accumulated more patients and reevaluated the significance of MRD. We also compared the two methods of MRD detection: PCR amplification and flow cytometry. 


\section{Patients and methods}

\section{Patient characteristics}

A total of 46 adult ALL patients were included in the study during the period from May 2001 to December 2007 at Hokkaido University Hospital and hospitals associated with the Hokkaido Leukemia Study Group. They were registered with the study when the diagnoses of ALL were made. Twelve of the 46 patients who entered the study were excluded (patients with no IGH, TCR $\delta$, or TCR $\gamma$ clonal marker or fusion transcripts at diagnosis $(n=5)$, patients who died before or during induction chemotherapy $(n=5)$, and patients who did not achieve CR $(n=2))$. In total, MRD could be monitored in 34 of the 46 initial patients.

The characteristics of the 34 patients are summarized in Table 1. Seventeen (50.0\%) of the patients were male and $17(50.0 \%)$ were female. Their median age was 48.5 years (range, 15-79 years) and median duration of follow-up was 567.5 days (range, 49-2040 days). The median WBC count was $10.9 \times 10^{9} / \mathrm{L}$ (range, $1.7-3272.5 \times 10^{9} / \mathrm{L}$ ). Thirty patients had B-precursor ALL and 4 had T-ALL. Eighteen patients were Philadelphia $(\mathrm{Ph})$ chromosome-positive: 13 patients $(55.6 \%)$ had $\mathrm{p} 190^{\mathrm{BCR} / \mathrm{ABL}}$ transcripts, 3 patients $(16.7 \%)$ had $\mathrm{p} 210^{\mathrm{BCR} / \mathrm{ABL}}$ transcripts, and the other $2(11.1 \%)$ had both transcripts. One patient was positive for SIL/TAL1 and another patient was positive for E2A/PBX1, but 
these fusion transcripts were not used to detect MRD. Eighteen (52.9\%) of the 34

patients received chemotherapy only, and the remaining $16(47.1 \%)$ received allogeneic stem cell transplantation after chemotherapy. Eight patients had related donors and 8

patients had unrelated donors. Clinical characteristics of the patients are shown in Table

2.

Twenty-six patients were treated with intravenous cyclophosphamide, vincristine, daunorubicin or doxorubicin, etoposide, cytosine arabinoside, steroid, 1-asparaginase, with or without imatinib, and intrathecal methotrexate for induction therapy. One patient received only imatinib, another patient received etoposide and imatinib, and another patient was treated with idarubicin and cytosine arabinoside because the diagnosis of acute myelogenous leukemia was made at the first time. The induction therapies for other five patients were not known. The conditioning regimen for allogeneic transplantation consisted of total body irradiation in combination with cyclophosphamide and etoposide for 13 patients or fludarabine for 1 patient. The conditioning regimen was unknown for the other three patients.

Clinical decisions concerning treatment of the patients were made by their physicians regardless of MRD results. Enrollment in the study was contingent upon informed consent of the patient. The study was approved by the Institutional Review Board of 
Hokkaido University Graduate School of Medicine.

\section{Remission and relapse}

Morphologic CR was defined as less than 5\% blast cells in a regenerated bone marrow (BM) aspirate, absence of extramedullary leukemia, and peripheral blood (PB) neutrophil and platelet counts of $>1.5 \times 10^{9} / \mathrm{L}$ and $>100 \times 10^{9} / \mathrm{L}$, respectively. Clinical relapse was defined as detection of at least $5 \%$ blast cells in BM or detection of leukemic cells extramedullary.

\section{Sample processing}

$\mathrm{BM}$ or $\mathrm{PB}$ was collected at the time of initial diagnosis and at several clinical points (day 30 and day 100 after diagnosis, before the conditioning regimen, after transplantation and any points at the end of each chemotherapy). Some samples were collected after completion of the treatment. The samples were used for PCR study of IGH/TCR rearrangements and BCR/ABL fusion gene transcripts. Some of the samples were also used for flow cytometry study. A total of 231 samples (220 BM and 11 PB samples) were analyzed; the median number of samples analyzed per patient was 6 (range, 2-22) (Table 3). For a total of $27 \mathrm{BM}$ samples from five patients MRD was analyzed by both PCR amplification and flow cytometry. We did not evaluate the difference in values of MRD between BM and PB samples. 
Quantitative real-time PCR analysis of $B C R / A B L$

Samples were analyzed for BCR/ABL, TEL/AML1, MLL/AF4, MLL/AF9, MLL/AF6, MLL/ENL, E2A/PBX1, and SIL/TAL1 chimeric genes. Samples were amplified by real-time quantitative polymerase chain reaction (RQ-PCR) and quantified by parallel amplification of serial dilutions of transcript-containing plasmids. A $10^{-5}$ sensitivity for MRD detection could be obtained.

PCR analysis of IGH/TCR gene rearrangements

When a BCR/ABL chimeric fusion gene was not present, leukemia-specific probes were generated by genomic amplification and sequencing of VDJ regions of the immunoglobulin heavy chain (IGH) and T-cell receptor $\delta$ and $\gamma(\mathrm{TCR} \delta$ and TCR $\gamma)$ genes. The method of PCR analysis of IGH/TCR gene rearrangements has been described previously (5). The sensitivity was $10^{-3}$. When two MRD probes gave different results in the same patient, the higher MRD level was considered valid for the purpose of the study.

Flow cytometry

Leukemia-associated immunophenotypes were identified by flow cytometry with four-color combinations of monoclonal antibodies. The flow cytometric method used has been described previously (6). For each case, one or more marker combinations that 
allowed the identification of one leukemic cell in $10^{3}-10^{4}$ normal nucleated cells were selected at diagnosis and used to study MRD during therapy. This approach reached sensitivities up to $10^{-4}$.

Statistical analysis

Survival curves were plotted according to the method of Kaplan and Meier, and comparison of the curves was made using log-rank tests. Overall survival (OS) was measured from the date of induction therapy until death. Relapse-free survival (RFS) was measured from the date of induction therapy until the date of relapse or death, whichever occurred first. Univariate and multivariate analyses were performed to evaluate the independent prognostic factors for OS and RFS by a Cox regression model. 
Results

\section{Identification of MRD-PCR targets}

Eighteen patients were $\mathrm{Ph}$ chromosome-positive and their MRD was detected by $\mathrm{BCR} / \mathrm{ABL}$ fusion transcripts. Thirty IGH/TCR gene rearrangements were found at diagnosis in the 22 ALL patients: 19 IGH (two different kinds in five patients), 6 TCR $\delta$, and 5 TCR $\gamma$ gene rearrangements. Eight patients had two targets and 14 patients had one target (Table 3). MRD was analyzed by both BCR/ABL fusion transcripts and IGH/TCR gene rearrangements in 6 patients. The results obtained by the two methods were concordant. In 5 patients, MRD was also detected by flow cytometry (BCR/ABL, 4; IGH gene rearrangement, 1).

Patients achieved first CR after a median period of 35 days (range, 15-105 days). Sixteen patients $(47.1 \%)$ received allogeneic stem cell transplantation following induction and consolidation chemotherapy. Seventeen patients relapsed and 17 patients remained in $\mathrm{CR}$.

We analyzed 27 of the 34 patients who could be examined for MRD on day 100. The overall survival (OS) rate (45.0\%) and relapse-free survival (RFS) rate (40.0\%) at 2 years in CR patients with MRD level $\geq 10^{-3}(\mathrm{n}=12)$ were significantly lower than those 
in CR patients with MRD level $<10^{-3}(\mathrm{n}=15)$ (OS rate: $79.0 \%$, RFS rate: $\left.79.4 \%\right)$

(log-rank test, $P=0.017$ and 0.0007$)$. A lower MRD value on day 100 after induction therapy was associated significantly with longer survival (Fig.1a and b). Two patients were excluded from the study because of relapse before day 100 after induction therapy. Monitoring of MRD enabled prediction of relapse in 10 of the 14 relapsed patients whose results of MRD analyses were available before relapse. The median time from molecular to clinical relapse was 65 days (range, 12-305 days).

Comparison of the results obtained by flow cytometry and PCR analysis

We compared MRD levels determined by both flow cytometry and PCR analysis in 27 follow-up BM samples from 5 patients (Table 4). Four of them had Ph-positive ALL and MRD was analyzed by BCR/ABL fusion transcripts. The other patient was analyzed by IGH gene rearrangement. Concordance between the flow cytometric and PCR results was obtained in 17 (63.0\%) of the 27 samples $(P=0.057)$. No significant changes regarding immunophenotype were observed when MRD phenotypes at relapse were compared to the original phenotypes at diagnosis.

Of the 10 samples that were MRD-positive by flow cytometry but MRD-negative by PCR, very low levels (below $10^{-4}$ ) could be detected by flow cytometry in 5 samples 
from 2 patients. The other 5 samples from 3 patients were MRD-positive by flow cytometry $(0.18 \%, 0.16 \%, 0.39 \%, 0.42 \%$, and $2.53 \%)$ but MRD-negative by PCR.

\section{Other prognostic factors}

In addition, we examined factors correlated with OS and RFS by the log-rank test. In the log-lank test, a lower MRD value on day 100 was associated significantly with longer survival (Table 5). However, we could not determine other factors, such as age, WBC count at diagnosis, $\mathrm{Ph}$ chromosome, immunophenotype, sex, days to achieve CR, and type of treatment (chemotherapy or transplantation). Therefore, our data provide evidence that molecular MRD status on day 100 is a strong predictor of outcome in adult ALL.

\section{Relative risk of relapse}

Looking for informative predictors of the achievement of molecular CR on day 100, we used univariate and multivariate analyses to investigate the role of conventional clinical findings such as age younger than 55 years or not, WBC count at diagnosis, $\mathrm{Ph}$ chromosome, immunophenotype, sex, days to achieve CR, and MRD levels on day 30. Univariate analysis showed that MRD positivity on day 100 was associated with age older than 55 years and MRD positivity on day 30, but there were no significant associations in multivariate analysis. 


\section{Discussion}

There is increasing evidence that MRD has strong prognostic significance in adult patients with ALL. Mortuza et al. found that MRD positivity detected especially at 3 to 6 months after induction therapy in adults with B-ALL was associated with an increased risk of relapse (7). Holowiecki et al. reported that MRD equal or greater than $0.1 \%$ of bone marrow cells after induction was a strong and independent predictor for relapse in both standard and high-risk groups (2).

We also showed that OS and RFS at 2 years in CR patients positive for MRD by PCR-based detection of BCR/ABL transcripts or IGH/TCR gene rearrangements were significantly lower than those in CR patients negative for MRD.

Three highly specific and sensitive methodologies for MRD detection are available: multiparameter flow cytometric immunophenotyping, RQ-PCR-based detection of fusion gene transcripts or breakpoints, and PCR-based detection of clonal immunoglobulin and T-cell receptor gene rearrangements (8).

PCR-based detection of rearranged IGH/TCR genes is currently the most broadly applied MRD technique owing to its high level of standardization, its well-defined quantitative range and good sensitivity, as well as applicability in the majority of ALL 
patients (3). To reach a higher level of sensitivity, DNA sequencing of the junctional regions is required in order to design tumor-specific primers and/or probes.

A major drawback of using rearranged immune genes as MRD-PCR targets is the possible occurrence of continuing rearrangements during the course of therapy and during follow-up, which can lead to false-negative PCR results (9).

Relapse could not be predicted in 4 of the 14 relapsed patients in this study. In two of them, TCR $\delta$ or IGH gene rearrangement was not detected even at the time of relapse.

Clonal TCR $\delta$ rearrangement in particular can be lost during the follow-up period preceding relapse (10), and continuing rearrangements during the disease course occur in $10-40 \%$ of cases depending on the target used (11).

One specific advantage of flow cytometry over PCR-based assays is that it allows direct quantification of MRD, rather than extrapolating it from amounts of PCR product (9). However, the immunophenotype of leukemic cells may change during progression of the disease, and if these changes affect markers used for monitoring MRD, a false-negative finding may result $(12,13)$.

In this study, concordance between the flow cytometric and PCR results was obtained in $17(63.0 \%)$ of the 27 samples. Comparative analyses showed that more concordant results could be obtained for both methods at the level of $10^{-3}$ and $10^{-4}(14,15)$. In three 
cases, some samples showed discordant results. In these cases, MRD might be overestimated by flow cytometry because normal cells cannot be easily distinguished from leukemic cells in studies of MRD (6).

The combination use of the two methods may offset the possibility of false-negative and false-positive MRD results due to these events (16).

We did not find a significant prognostic value of MRD in patients who received allogeneic transplantation. It has been shown that MRD detected before transplantation was a significant predictor of failure after transplantation $(17,18)$. However, Patel et al. suggested that molecularly determined MRD pre-transplant was not a risk factor for relapse in patients receiving allogeneic stem cell transplantation in the first CR (19). It has also been shown that MRD status after allogeneic transplantation was an important predictor of outcome in adults with $\operatorname{ALL}(7,18)$. The MRD status before and after transplantation was not correlated with survival in this study, which may be explained by the small number of patients who received transplantation.

Results of log-rank tests showed that age, WBC count at diagnosis, sex, Ph-positivity, and immunophenotype were not associated with prognosis or relapse. Generally, advanced age of the patient and high WBC count at diagnosis with acute leukemia are related to poor prognosis. In this study, we did not intervene in clinical decisions 
concerning treatment of the patients, but MRD level on day 100 after induction

chemotherapy was only a good prognostic factor to monitor relapse and classify the groups as good or poor prognosis.

Although limitation of MRD assessment for prediction of extramedullary relapse is recognized (19), MRD methods can be used to predict outcome on the basis of early response to therapy and to recognize leukemia relapse (20).

Thorn et al. suggested that MRD levels calculated by the quantification of BCR/ABL transcripts were higher than levels obtained by flow cytometry and by quantitative PCR of rearranged IGH/TCR genes (21). However, whether the results of these methods coincide with those of PCR amplification of fusion transcripts is not yet established (22). Further progress in how to assess MRD and improve the prognosis in adult patients with ALL in association with MRD is expected.

In this study, we investigated the prognostic value of MRD in adult patients with ALL. We found that ALL patients with MRD level $<10^{-3}$ on day 100 had significantly better OS and RFS than those of ALL patients with MRD level $\geq 10^{-3}$. Therefore, MRD analysis is useful for monitoring the prognosis of ALL patients. PCR analysis and flow cytometry were both useful for the detection of MRD. However, both methods can yield false-negative and false-positive results, and improvements are needed for further 
1

2

optimization and standardization to assess MRD. It is important to investigate an appropriate way to choose among these methods or use of them in tandem. 
1

2

3

4

5

6

7

8

9

10

11

12

13

14

15

16

17

18

19

20

21

22

23

24

25

26

27

28

29

30

31

32

33

34

35

36

37

38

39

40

41

42

43

44

45

46

47

48

49

50

51

52

53

54

55

56

57

58

59

60

61

62

63

64

65

\section{Acknowledgments}

This work was supported in part by Kyowa-Kirin, Japan (Tokyo, Japan). 


\section{References}

1. Bassan R, Spinelli O, Oldani E, Intermesoli T, Tosi M, Peruta B, et al. Improved risk classification for risk-specific therapy based on the molecular study of minimal residual disease (MRD) in adult acute lymphoblastic leukemia (ALL). Blood 2009;

113:4153-62.

2. Holowiecki J, Krawczyk-Kulis M, Giebel S, Jagoda K, Stella-Holowiecka B,

Piatkowska-Jakubas B, et al. Status of minimal residual disease after induction predicts outcome in both standard and high-risk Ph-negative adult acute lymphoblastic leukaemia. The Polish Adult Leukemia Group ALL 4-2002 MRD Study. Br J Haematol. $2008 ; 142: 227-37$

3. Brüggemann M, Schrauder A, Raff T, Pfeifer H, Dworzak M, Ottmann OG, et al. Standardized MRD quantification in European ALL trials: proceedings of the Second International Symposium on MRD assessment in Kiel, Germany, 18-20 September 2008. Leukemia 2010; 24:521-35.

4. Campana D, Coustan-Smith E. Minimal residual disease studies by flow cytometry in acute leukemia. Acta Haematol. 2004; 112:8-15.

5. Toubai T, Tanaka J, Ota S, Fukuhara T, Hashino S, Kondo T, et al. Minimal residual 
disease (MRD) monitoring using rearrangement of T-cell receptor and immunoglobulin

$\mathrm{H}$ gene in the treatment of adult acute lymphoblastic leukemia patients. Am J Hematol.

$2005 ; 80: 181-7$.

6. Chen JS, Coustan-Smith E, Suzuki T, Neale GA, Mihara K, Pui CH, et al.

Identification of novel markers for monitoring minimal residual disease in acute

lymphoblastic leukemia. Blood 2001; 97:2115-20.

7. Mortuza FY, Papaioannou M, Moreira IM, Coyle LA, Gameiro P, Gandini D, et al.

Minimal residual disease tests provide an independent predictor of clinical outcome in adult acute lymphoblastic leukemia. J Clin Oncol. 2002; 20:1094-104.

8. Szczepański T. Why and how to quantify minimal residual disease in acute lymphoblastic leukemia? Leukemia 2007; 21:622-6.

9. Brüggemann M, Pott C, Ritgen M, Kneba M. Significance of minimal residual disease in lymphoid malignancies. Acta Haematol. 2004; 112:111-9.

10. Foroni L, Hoffbrand AV. Molecular analysis of minimal residual disease in adult acute lymphoblastic leukaemia. Best Pract Res Clin Haematol. 2002; 15:71-90.

11. Szczepański T, Willemse MJ, Brinkhof B, van Wering ER, van der Burg M, van

Dongen JJ. Comparative analysis of Ig and TCR gene rearrangements at diagnosis and at relapse of childhood precursor-B-ALL provides improved strategies for selection of 
stable PCR targets for monitoring of minimal residual disease. Blood 2002; 99:2315-23.

12. Brisco J, Hughes E, Neoh SH, Sykes PJ, Bradstock K, Enno A, et al. Relationship between minimal residual disease and outcome in adult acute lymphoblastic leukemia.

Blood 1996; 87:5251-6.

13. Radich J, Gehly G, Lee A, Avery R, Bryant E, Edmands S, et al. Detection of bcr-abl transcripts in Philadelphia chromosome-positive acute lymphoblastic leukemia after marrow transplantation. Blood 1997; 89:2602-9.

14. Kerst G, Kreyenberg H, Roth C, Well C, Dietz K, Coustan-Smith E, et al. Concurrent detection of minimal residual disease (MRD) in childhood acute lymphoblastic leukaemia by flow cytometry and real-time PCR. Br J Haematol. 2005; 128:774-82.

15. Robillard N, Cavé H, Méchinaud F, Guidal C, Garnache-Ottou F, Rohrlich PS, et al. Four-color flow cytometry bypasses limitations of IG/TCR polymerase chain reaction for minimal residual disease detection in certain subsets of children with acute lymphoblastic leukemia. Haematologica 2005; 90:1516-23.

16. Neale GA, Coustan-Smith E, Stow P, Pan Q, Chen X, Pui CH, et al. Comparative analysis of flow cytometry and polymerase chain reaction for the detection of minimal residual disease in childhood acute lymphoblastic leukemia. Leukemia 2004; 18:934-8. 
value of immunological monitoring of minimal residual disease in acute lymphoblastic leukaemia after allogeneic transplantation. Br J Haematol. 2002; 116:686-94.

18. Spinelli O, Peruta B, Tosi M, Guerini V, Salvi A, Zanotti MC, et al. Clearance of minimal residual disease after allogeneic stem cell transplantation and the prediction of the clinical outcome of adult patients with high-risk acute lymphoblastic leukemia. Haematologica 2007; 92:612-8.

19. Patel B, Rai L, Buck G, Richards SM, Mortuza Y, Mitchell W, et al. Minimal residual disease is a significant predictor of treatment failure in non T-lineage adult acute lymphoblastic leukaemia: final results of the international trial UKALL XII/ECOG2993. Br J Haematol. 2010; 148:80-9.

20. Campana D. Role of minimal residual disease monitoring in adult and pediatric acute lymphoblastic leukemia. Hematol Oncol Clin North Am. 2009; 23:1083-98. 21. Thörn I, Botling J, Hermansson M, Lönnerholm G, Sundström C, Rosenquist R, et al. Monitoring minimal residual disease with flow cytometry, antigen-receptor gene rearrangements and fusion transcript quantification in Philadelphia-positive childhood acute lymphoblastic leukemia. Leuk Res. 2009; 33:1047-54.

22. Campana D. Minimal residual disease in acute lymphoblastic leukemia. Semin 
1

2

3

4

5

7

8

10

11

12

13

14

15

16

17

18

19

20

21

22

23

24

25

26

27

28

29

30

31

32

33

34

35

36

37

38

39

40

41

42

43

44

45

46

47

48

49

50

51

52

53

54

55

56

57

58

59

60

61

62

63

64

65

Hematol. 2009; 46:100-6. 
1

2

3

4

5

6

7

8

9

\section{Figure legends}

Figure 1. Comparison of overall survival (OS, a) and relapse-free survival (RFS, b) by MRD detection on day 100 after induction therapy. 
Table 1. Characteristics of the patients.

\begin{tabular}{|c|c|}
\hline Characteristics & $\mathrm{N}$ \\
\hline Number of patients & 34 \\
\hline \multicolumn{2}{|l|}{ Gender $(\%)$} \\
\hline Male & $17(50.0 \%)$ \\
\hline Female & $17(50.0 \%)$ \\
\hline Median age, years (range) & $48.5(15-79)$ \\
\hline \multicolumn{2}{|l|}{ Age } \\
\hline$<35$ years & $14(41.2 \%)$ \\
\hline$\geq 35$ years & $20(58.8 \%)$ \\
\hline$<55$ years & $21(61.8 \%)$ \\
\hline$\geq 55$ years & $13(38.2 \%)$ \\
\hline Median follow-up period, days (range) & $567.5(49-2040)$ \\
\hline \multicolumn{2}{|l|}{ Immunophenotype } \\
\hline B-ALL & $30(88.2 \%)$ \\
\hline T-ALL & $4(11.8 \%)$ \\
\hline Median WBC, $\times 10^{9} / \mathrm{L}$ (range) & $10.9(1.7-3272.5)$ \\
\hline WBC $<30 \times 10^{9} / \mathrm{L}(\mathrm{B}),<100 \times 10^{9} / \mathrm{L}(\mathrm{T})$ & $25(73.5 \%)$ \\
\hline $\mathrm{WBC} \geq 30 \times 10^{9} / \mathrm{L}(\mathrm{B}), \geq 100 \times 10^{9} / \mathrm{L}(\mathrm{T})$ & $5(14.7 \%)$ \\
\hline unknown & $4(11.8 \%)$ \\
\hline Median hemoglobin, g/dL (range) & $10.3(4.1-14.9)$ \\
\hline Median platelet, $\times 10^{9} / \mathrm{L}$ (range) & $50.5(3-302)$ \\
\hline Median LDH, IU/L (range) & $730(206-11730)$ \\
\hline \multicolumn{2}{|l|}{ Philadelphia chromosome } \\
\hline negative & $16(47.1 \%)$ \\
\hline positive & $18(52.9 \%)$ \\
\hline $\mathrm{p} 190^{\mathrm{BCR} / \mathrm{ABL}}$ & $13(38.2 \%)$ \\
\hline $\mathrm{p} 210^{\mathrm{BCR} / \mathrm{ABL}}$ & $3(8.8 \%)$ \\
\hline $\mathrm{p} 190^{\mathrm{BCR} / \mathrm{ABL}}$ and $\mathrm{p} 210^{\mathrm{BCR} / \mathrm{ABL}}$ & $2(5.9 \%)$ \\
\hline
\end{tabular}


Treatment

Chemotherapy

$18(52.9 \%)$

Chemotherapy $\rightarrow$ Transplantation

$16(47.1 \%)$

Conditioning

Myeloablative

$12(75.0 \%)$

Reduced intensity

$2(12.5 \%)$

unknown

$2(12.5 \%)$

Stem cell source

Bone Marrow

$6(37.5 \%)$

Peripheral Blood

$7(43.8 \%)$

Cord Blood

$3(18.8 \%)$

Median time to $\mathrm{CR}$, days (range)

$35(15-105)$

Outcome at 2 years

Overall survival

$54.6 \%$

Relapse-free survival

$51.8 \%$ 
Table 2. Clinical characteristics and outcome of the patients.

\begin{tabular}{|c|c|c|c|c|c|c|c|c|c|}
\hline $\begin{array}{r}\text { Patient } \\
\text { no. }\end{array}$ & $\begin{array}{l}\text { Sex/ } \\
\text { age }\end{array}$ & $\begin{array}{l}\text { Immuno- } \\
\text { phenotype }\end{array}$ & $\begin{array}{c}\text { WBC } \\
\left(\mathrm{X} 10^{9} / \mathrm{L}\right)\end{array}$ & $\begin{array}{c}\mathrm{Ph} \\
\text { choromosome }\end{array}$ & MRD markers & $\begin{array}{c}\text { Transplan- } \\
\text { tation }\end{array}$ & $\begin{array}{c}\text { MRD } \\
\text { day100 }\end{array}$ & Outcome & \\
\hline 1 & $\mathrm{M} / 28$ & B & 16.6 & No & $\operatorname{IgH}$ & No & positive & REL d195 & D d 218 \\
\hline 2 & $\mathrm{~F} / 59$ & B & 13 & Yes & $\operatorname{IgH}, \mathrm{p} 190^{\mathrm{BCR} / \mathrm{ABL}}$ & No & positive & REL d 245 & D d617 \\
\hline 3 & $\mathrm{M} / 53$ & B & 1.7 & Yes & $\operatorname{IgH}, \mathrm{p} 210^{\mathrm{BCR} / \mathrm{ABL}}$ & No & $*$ & REL d 159 & $\mathrm{D} d 280$ \\
\hline 4 & $\mathrm{M} / 50$ & B & 12.2 & No & TCR $\delta$ & Yes & negative & REL d494 & D d518 \\
\hline 5 & $\mathrm{M} / 77$ & B & 16.8 & Yes & $\operatorname{IgH}, \mathrm{p} 190^{\mathrm{BCR} / \mathrm{ABL}}$ & No & positive & REL d807 & D d1003 \\
\hline 6 & $\mathrm{~F} / 25$ & $\mathrm{~T}$ & 38 & No & $\mathrm{TCR} \gamma$ & Yes & negative & CR d 2040 & A d 2040 \\
\hline 7 & $\mathrm{~F} / 47$ & B & 3.7 & Yes & $\operatorname{IgH}, \mathrm{p} 190^{\mathrm{BCR} / \mathrm{ABL}}$ & Yes & negative & CR d1989 & A d1989 \\
\hline 8 & M57 & B & 23 & No & $\operatorname{IgH}$ & No & positive & REL d 141 & D d502 \\
\hline 9 & $F / 37$ & B & 3 & Yes & $\mathrm{TCR} \delta, \mathrm{p} 190^{\mathrm{BCR} / \mathrm{ABL}}$ & Yes & negative & CR d769 & A d769 \\
\hline 10 & $\mathrm{~F} / 60$ & B & 3 & No & TCR $\delta$ & No & positive & REL d995 & A d1892 \\
\hline 11 & $\mathrm{~F} / 63$ & B & 3272.5 & Yes & $\mathrm{p} 210^{\mathrm{BCR} / \mathrm{ABL}}$ & No & positive & REL d49 & D d309 \\
\hline 12 & $\mathrm{~F} / 65$ & B & 141.1 & Yes & $\mathrm{TCR} \delta, \gamma, \mathrm{p} 190^{\mathrm{BCR} / \mathrm{ABL}}$ & No & positive & REL d47 & D d 320 \\
\hline 13 & $\mathrm{M} / 52$ & B & 10.4 & Yes & $\mathrm{p} 210^{\mathrm{BCR} / \mathrm{ABL}}$ & No & negative & CR d 483 & A d 483 \\
\hline 14 & $\mathrm{M} / 23$ & $\mathrm{~T}$ & 8.4 & No & $\mathrm{TCR} \delta, \gamma$ & Yes & negative & CR d 1604 & A d 1604 \\
\hline 15 & $\mathrm{M} / 21$ & $\mathrm{~T}$ & 10 & No & $\mathrm{TCR} \gamma$ & Yes & positive & REL d 280 & D d 385 \\
\hline 16 & $\mathrm{~F} / 60$ & B & 2 & No & $\operatorname{IgH}$ & No & negative & CR d 1463 & A d 1463 \\
\hline 17 & $F / 31$ & B & 6 & No & $\operatorname{IgH}$ & Yes & negative & REL d382 & D d501 \\
\hline
\end{tabular}




\begin{tabular}{|c|c|c|c|c|c|c|c|c|c|}
\hline 18 & $\mathrm{M} / 15$ & B & 6.3 & No & $\operatorname{IgH}$ & Yes & negative & CR d 1339 & A d 1339 \\
\hline 19 & $\mathrm{M} / 62$ & B & 2.2 & No & $\operatorname{IgH}$ & No & positive & REL d889 & D d1138 \\
\hline 20 & $\mathrm{~F} / 19$ & $\mathrm{~T}$ & 3.3 & No & $\mathrm{TCR} \delta, \gamma$ & Yes & positive & CR d 1169 & A d 1169 \\
\hline 21 & $\mathrm{~F} / 79$ & B & $*$ & No & $\operatorname{IgH}$ & No & positive & REL d346 & D d360 \\
\hline 22 & $\mathrm{~F} / 19$ & B & 155.2 & No & $\mathrm{IgH}$ & Yes & negative & CR d469 & D d469 \\
\hline 23 & $\mathrm{M} / 72$ & B & 3.8 & Yes & $\mathrm{p} 190^{\mathrm{BCR} / \mathrm{ABL}}$ & No & negative & CR d948 & A d948 \\
\hline 24 & $\mathrm{M} / 46$ & B & $*$ & Yes & $\mathrm{p} 190^{\mathrm{BCR} / \mathrm{ABL}}$ & Yes & $*$ & REL d399 & A d 964 \\
\hline 25 & $\mathrm{~F} / 50$ & B & 4 & Yes & $\mathrm{p} 190^{\mathrm{BCR} / \mathrm{ABL}}$ & Yes & negative & CR d840 & A d 840 \\
\hline 26 & $\mathrm{M} / 33$ & B & 230 & Yes & $\mathrm{p} 190^{\mathrm{BCR} / \mathrm{ABL}}$ & No & negative & CR d720 & A d 720 \\
\hline 27 & $\mathrm{M} / 72$ & B & $*$ & Yes & $\mathrm{p} 190^{\mathrm{BCR} / \mathrm{ABL}}$ & No & - & CR d 49 & $\mathrm{D} d 49$ \\
\hline 28 & $\mathrm{~F} / 26$ & B & 24.9 & Yes & $\mathrm{p} 190^{\mathrm{BCR} / \mathrm{ABL}}$ & Yes & $*$ & CR d738 & A d 738 \\
\hline 29 & $\mathrm{~F} / 68$ & B & $*$ & Yes & $\mathrm{p} 190^{\mathrm{BCR} / \mathrm{ABL}}, \mathrm{p} 210^{\mathrm{BCR} / \mathrm{ABL}}$ & No & * & REL * & D d 352 \\
\hline 30 & $\mathrm{M} / 25$ & B & 11.3 & No & $\operatorname{IgH}$ & Yes & negative & CR d640 & A d 640 \\
\hline 31 & $\mathrm{~F} / 26$ & B & 8.6 & No & $\operatorname{IgH}$ & Yes & $*$ & REL d 158 & D d354 \\
\hline 32 & $\mathrm{~F} / 31$ & B & 24.1 & Yes & $\mathrm{p} 190^{\mathrm{BCR} / \mathrm{ABL}}, \mathrm{p} 210^{\mathrm{BCR} / \mathrm{ABL}}$ & Yes & negative & REL d 262 & A d 325 \\
\hline 33 & $\mathrm{M} / 28$ & B & 16.8 & Yes & $\mathrm{p} 190^{\mathrm{BCR} / \mathrm{ABL}}$ & No & negative & CR d 120 & A d 120 \\
\hline 34 & $\mathrm{M} / 77$ & B & 36.7 & Yes & $\mathrm{p} 190^{\mathrm{BCR} / \mathrm{ABL}}$ & No & positive & $\mathrm{CR} \mathrm{d} 125$ & A d 125 \\
\hline
\end{tabular}

*The data was unknown.

Ph indicates philadelphia, REL; relapse; D, dead; A, alive. 
Table 3. MRD studies.

Total 34

BCR/ABL transcripts $\quad 12$

$\mathrm{p} 190^{\mathrm{BCR} / \mathrm{ABL}} \quad 8$

$\mathrm{p} 210^{\mathrm{BCR} / \mathrm{ABL}} 2$

$\mathrm{p} 190^{\mathrm{BCR} / \mathrm{ABL}}$ and $\mathrm{p} 210^{\mathrm{BCR} / \mathrm{ABL}} 2$

IGH, TCR $\delta$, TCR $\gamma$ gene rearrangement patterns 16

Monoclonal 10

IGH 6

TCR $\delta$ 2

TCR $\gamma$

Diclonal 6

2 clones of IGH 4

TCR $\delta$ and TCR $\gamma \quad 2$

BCR/ABL and IGH/TCR rearrangements 6

$\mathrm{p} 190^{\mathrm{BCR} / \mathrm{ABL}}$ and IGH 2

$\mathrm{p} 190^{\mathrm{BCR} / \mathrm{ABL}}$ and 2 clones of IGH 1

$\mathrm{p} 210^{\mathrm{BCR} / \mathrm{ABL}}$ and IGH 1

$\mathrm{p} 190^{\mathrm{BCR} / \mathrm{ABL}}$ and TCR $\delta \quad 1$

$\mathrm{p} 190^{\mathrm{BCR} / \mathrm{ABL}}$ and TCR $\delta$, TCR $\gamma \quad 1$

Number of samples 231

Median (range) 6

Bone marrow 220

$\begin{array}{ll}\text { Peripheral blood } & 11\end{array}$ 
Figure 1a

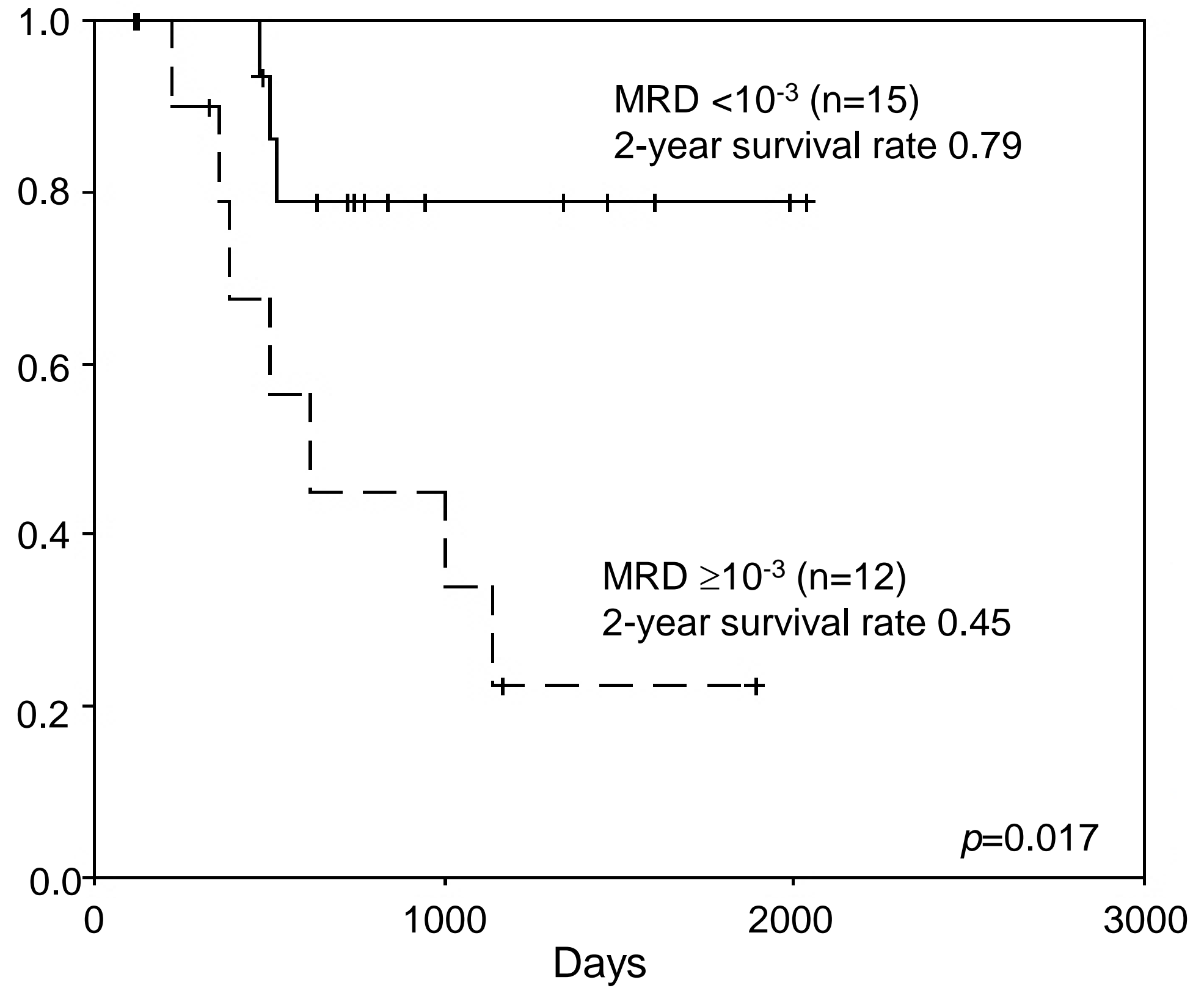


Figure 1b

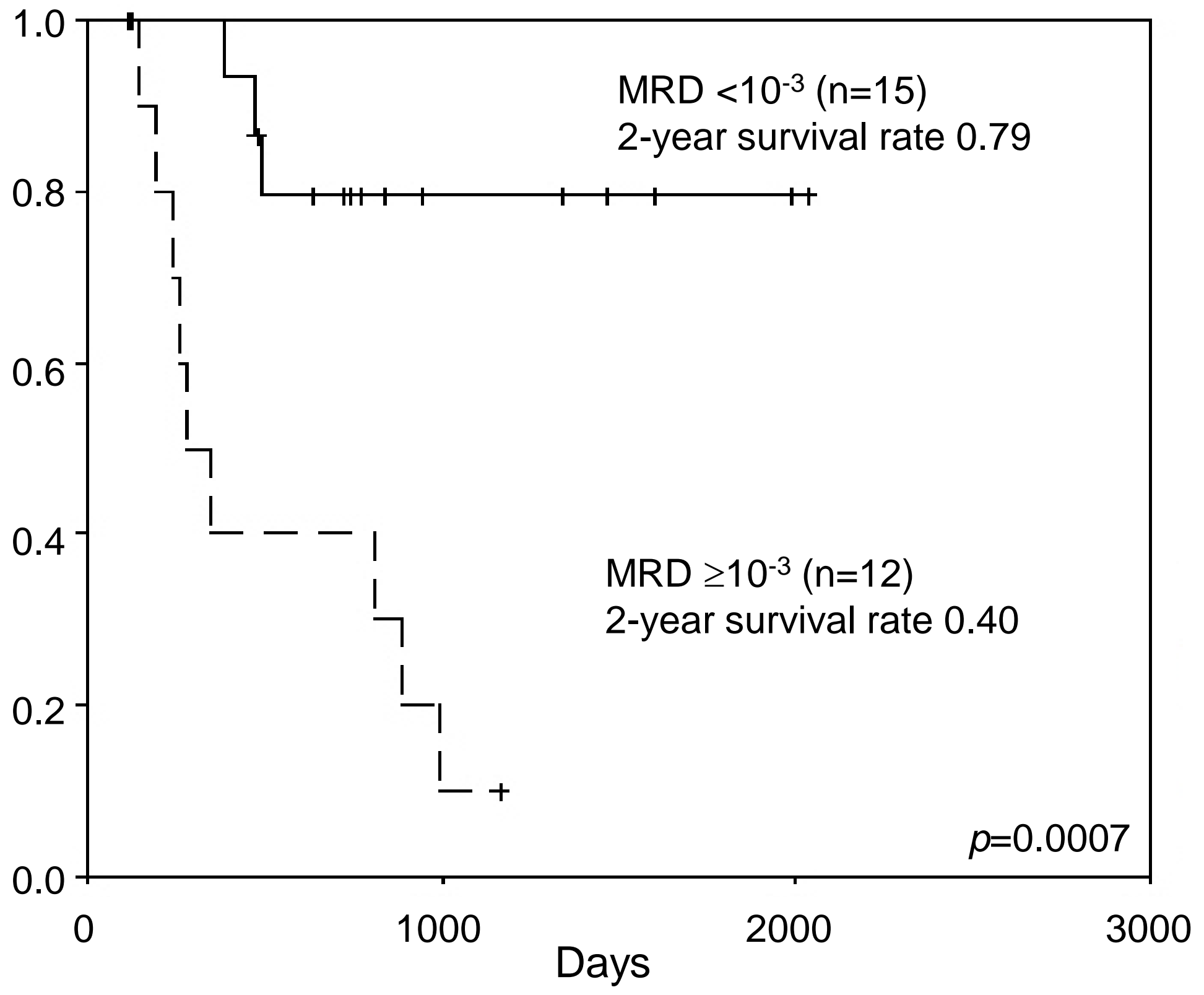


Table 4. Informative CD combinations used for flow cytometry (FC).

\begin{tabular}{|c|c|c|c|c|c|}
\hline \multirow[b]{2}{*}{ Case } & \multirow[b]{2}{*}{ Type } & & \multicolumn{3}{|c|}{ MRD results } \\
\hline & & $\begin{array}{l}\text { Marker combinations } \\
\text { used at follow-up }\end{array}$ & $\begin{array}{l}\mathrm{PCR}+ \\
\mathrm{FC}+\end{array}$ & $\begin{array}{l}\text { PCR - } \\
\text { FC - }\end{array}$ & $\begin{array}{l}\text { PCR - } \\
\mathrm{FC} \mathrm{+}\end{array}$ \\
\hline 9 & ALL(B) & $\begin{array}{c}\mathrm{CD} 58 / \mathrm{CD} 45 / \mathrm{CD} 34 / \mathrm{CD} 19 \\
\mathrm{CD} 13 / \mathrm{CD} 10 / \mathrm{CD} 34 / \mathrm{CD} 19 \\
\mathrm{TdT} / \mathrm{CD} 10 / \mathrm{CD} 34 / \mathrm{CD} 19\end{array}$ & 1 & & \\
\hline 23 & Ph-ALL(B) & $\begin{array}{c}\text { CD58/CD45/CD34/CD19 } \\
\text { CD58/KOR-SA/CD34/CD19 } \\
\text { TdT/CD10/CD34/CD19 }\end{array}$ & 5 & 3 & 7 \\
\hline 24 & Ph-ALL(B) & $\begin{array}{c}\text { CD58/CD45/CD34/CD19 } \\
\text { CD10/KOR-SA/CD34/CD19 } \\
\text { TdT/CD33/CD34/CD19 }\end{array}$ & 3 & & 2 \\
\hline 25 & Ph-ALL(B) & $\begin{array}{c}\text { CD58/CD45/CD34/CD19 } \\
\text { CD10/KOR-SA/CD34/CD19 } \\
\text { TdT/CD10/CD34/CD19 }\end{array}$ & 1 & 1 & 1 \\
\hline 26 & Ph-ALL(B) & $\begin{array}{c}\text { CD58/CD45/CD34/CD19 } \\
\text { CD10/KOR-SA/CD34/CD19 } \\
\text { TdT/CD10/CD34/CD19 }\end{array}$ & 3 & & \\
\hline
\end{tabular}


Table 5. Univariate and multivariate analyses of prognostic factors associated with overall survival and relapse-free survival (log-rank test).

\begin{tabular}{|c|c|c|c|c|c|c|c|c|c|c|c|c|c|c|}
\hline \multirow[b]{3}{*}{ Variables } & \multicolumn{8}{|c|}{ Univariate } & \multicolumn{6}{|c|}{ Multivariate } \\
\hline & \multicolumn{3}{|c|}{ Overall survival } & \multicolumn{5}{|c|}{ Relapse-free survival } & \multicolumn{2}{|c|}{ Overall survival } & \multicolumn{4}{|c|}{ Relapse-free survival } \\
\hline & $\mathrm{N}$ & $\begin{array}{c}\text { Hazard } \\
\text { ratio }\end{array}$ & $95 \% \mathrm{CI}$ & $\begin{array}{c}p \\
\text { value }\end{array}$ & $\mathrm{N}$ & $\begin{array}{c}\text { Hazard } \\
\text { ratio }\end{array}$ & $95 \% \mathrm{CI}$ & $\begin{array}{c}p \\
\text { value }\end{array}$ & $\begin{array}{c}\text { Hazard } \\
\text { ratio }\end{array}$ & $95 \% \mathrm{CI}$ & $\begin{array}{c}p \\
\text { value }\end{array}$ & $\begin{array}{c}\text { Hazard } \\
\text { ratio }\end{array}$ & $95 \% \mathrm{CI}$ & $\begin{array}{c}p \\
\text { value }\end{array}$ \\
\hline \multicolumn{15}{|l|}{ Age (years) } \\
\hline$<35$ & 14 & 1.59 & $(0.55-4.59)$ & 0.39 & 14 & 1.83 & $(0.63-5.29)$ & 0.26 & & & & & & \\
\hline$\geq 35$ & 20 & & & & 19 & & & & & & & & & \\
\hline$<55$ & 21 & 2.34 & $(0.87-6.30)$ & 0.09 & 21 & 2.28 & $(0.85-6.14)$ & 0.10 & 0.42 & $(0.01-14.67)$ & 0.63 & 0.64 & $(0.04-10.26)$ & 0.75 \\
\hline$\geq 55$ & 13 & & & & 12 & & & & & & & & & \\
\hline \multicolumn{15}{|l|}{$\mathrm{WBC}\left(\times 10^{9} / \mathrm{L}\right)$} \\
\hline$<30(\mathrm{~B}),<100(\mathrm{~T})$ & 25 & 3.60 & $(0.93-13.91)$ & 0.06 & 25 & 3.05 & $(0.82-11.38)$ & 0.10 & 4.03 & $(0.12-134.40)$ & 0.44 & 4.00 & $(0.24-66.21)$ & 0.33 \\
\hline$\geq 30(\mathrm{~B}), \geq 100(\mathrm{~T})$ & 5 & & & & 5 & & & & & & & & & \\
\hline \multicolumn{15}{|l|}{ Gender } \\
\hline Female & 17 & 0.88 & $(0.33-2.36)$ & 0.80 & 16 & 1.10 & $(0.41-2.92)$ & 0.85 & & & & & & \\
\hline Male & 17 & & & & 17 & & & & & & & & & \\
\hline \multicolumn{15}{|l|}{$\mathrm{Ph}$ chromosome } \\
\hline negative & 16 & 1.03 & $(0.37-2.83)$ & 0.95 & 16 & 1.11 & $(0.40-3.04)$ & 0.84 & & & & & & \\
\hline positive & 18 & & & & 17 & & & & & & & & & \\
\hline \multicolumn{15}{|l|}{ Time to CR (days) } \\
\hline$<30$ & 10 & 1.18 & $(0.38-3.73)$ & 0.77 & 10 & 0.62 & $(0.22-1.76)$ & 0.37 & & & & & & \\
\hline$\geq 30$ & 23 & & & & 22 & & & & & & & & & \\
\hline \multicolumn{15}{|l|}{ Immunophenotype } \\
\hline B-lineage & 30 & 0.30 & $(0.04-2.34)$ & 0.25 & 29 & 0.27 & $(0.04-2.10)$ & 0.21 & & & & & & \\
\hline T-lineage & 4 & & & & 4 & & & & & & & & & \\
\hline \multicolumn{15}{|l|}{ Transplantation } \\
\hline No & 18 & 0.34 & $(0.12-0.97)$ & 0.04 & 17 & 0.40 & $(0.14-1.10)$ & 0.08 & 0.74 & $(0.03-21.18)$ & 0.86 & 0.75 & $(0.06-10.16)$ & 0.83 \\
\hline
\end{tabular}


MRD on day 30 negative

$\begin{array}{llll}7 & 1.13 & (0.35-3.70) & 0.84\end{array}$

7

1.64

$(0.51-5.25)$

0.41

positive

18

17

MRD on day 100

negative

$15 \quad 4.54 \quad(1.17-17.67) \quad 0.03$

positive

12

$15 \quad 7.14$

$(1.91-26.66)$

0.003

7.46

$(1.21-45.91)$

0.03

9.60

$(1.83-50.49)$

0.008

Ph indicates Philadelphia. 